YEARBOOK

of ANTITRUST

and REGULATORY

STUDIES

www.yars.wz.uw.edu.pl
Peer-reviewed scientific periodical, focusing on legal and economic issues of antitrust and regulation. Creative Commons Attribution-No Derivative Works 3.0 Poland License.

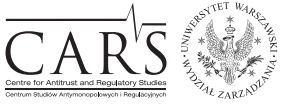

Centre for Antitrust and Regulatory Studies, University of Warsaw, Faculty of Management www.cars.wZ.uw.edu.pl

\title{
Heading Towards an Effective Mechanism for the Protection of Collective Interests of Consumers - Some Comments on the Proposal for a Directive on Representative Actions
}

by

\author{
Jagna Mucha*
}

\section{CONTENTS}

I. Introductory remarks

II. Different routes to developing the legislative framework for collective consumer redress in the EU

III. Model for protection of collective consumer interests in the EU provided in Directive 2009/22/EC

IV. Weaknesses of the existing model

1. Limited application of cross-border actions for an injunction

2. Costs, length and complexity of the proceedings

3. Limited effect of the ruling with respect of the case and the parties involved

4. Limited spectrum of legal remedies

V. Change for the better? Proposal for a Directive on representative actions

1. Cross-border representative actions

2. Legal costs and financing of qualified entities

3. Duration of the proceedings

4. Extended scope of application

VI. Evaluation of the changes proposed

* PhD, University of Warsaw; the following paper constitutes a part of the research conducted within the framework of the project funded by the grant no. UMO-2018/28/C/HS5/00083, 'Consumer collective redress in the group proceedings in the Polish legal system in the light of the European Union law standards-achievements and challenges', financed by the National Science Centre of Poland; jagna.mucha@uw.edu.pl. Article received: 10 June 2019; accepted: 4 July 2019. 


\section{Abstract}

In April 2018, the European Commission introduced a long awaited Proposal for a Directive on represented actions, which aims to modernize the existing European collective redress system. The aim of this paper is to answer the question whether the solutions put forward in this Proposal will improve the landscape of collective redress in the EU. For this purpose, I analyse the existing model of collective consumer redress in the EU, as set forth by Directive 98/27/EC, Directive 2009/22/ EC and Recommendation 2013/396/EU; I also evaluate it from the perspective of its functionality with special consideration of key problematic issues. Against this background, I present the legal provisions put forward in the Proposal for a Directive on representative actions. The comparison of both legal structures makes it possible to give an answer to the question whether the proposed legislation can remedy the existing problems of the collective redress system and, thus, to answer the question whether it will contribute to strengthening the mechanism for the protection of collective consumer interests in the EU.

\section{Résumé}

La Commission européenne a présenté en avril 2018 une proposition de directive tant attendue sur les actions représentées, qui vise à moderniser le système européen de recours collectif en vigueur. Lobjectif du présent article est de déterminer si les solutions proposées dans la proposition amélioreront le cadre des recours collectifs dans l'UE. A cette fin, l'article analyse le modèle existant de recours collectif des consommateurs dans l'UE, tel qu'il est défini par la directive 98/27/CE, la directive 2009/22/CE et la recommandation 2013/396/UE; il l'évalue également du point de vue de sa fonctionnalité en accordant une attention particulière aux questions problématiques essentielles. Dans ce contexte, l'article décrit les dispositions juridiques avancées dans la proposition de directive relative aux actions représentatives. La comparaison des deux structures juridiques permet de répondre à la question si la législation proposée peut remédier aux problèmes existants du système de recours collectif et, partant, si elle contribuera à renforcer le mécanisme de protection des intérêts collectifs des consommateurs dans l'UE.

Key words: collective redress, collective interests of consumers, consumer law, law enforcement, class action, representative actions, directive 2009/22/EC, Proposal for a Directive on the representative actions, A New Deal for Consumers, action for an injunction.

JEL: K23, K33, K41 


\section{Introductory remarks}

Collective redress is a an umbrella term which covers a wide range of procedural mechanisms tailored for collective enforcement of consumer law. Although these mechanisms are very diverse - collective redress models and types differ significantly worldwide - they serve the same purpose, namely to enable a great number of claimants to seek redress. ${ }^{1}$ Micklitz and Durovic classifies four major forms of collective redress: i) the representative action, in which standing to bring an action on behalf of the group in order to get redress is granted to a representative entity, ii) the group action, in which the aforementioned legal standing is granted to a member of the group, iii) the model or test case, in which the action is initiated by one or more persons and in which the adopted judgment establishes the grounds for other cases brought against the same defendant and, iv) United States class action style, which is a form of group action led by professional lawyers who receive fees for their services and claim compensation for the clients (Durovic and Micklitz, 2017, p. 81).

However, in EU law and policy, the term collective redress is used in opposition to the U.S. style class action system, which is widely criticised by EU institutions. Over the years, within the debate on the desired shape of the EU model of collective redress, the European Commission kept arguing that although U.S. class action system is the best known example of collective redress, its functioning is highly controversial since it fosters a conflict of interests, which results in frivolous and abusive litigation. ${ }^{2}$ It is said by the Commission that the biggest weaknesses of the U.S. style class action system is that it allows the cases to be based on poor merits on one hand, and claimants do not receive adequate compensation since the money is diverted to their lawyers on the other (Hodges, 2014, p. 71-75). Therefore, it shall not be applied in the EU. ${ }^{3}$ In order to avoid the above mentioned problems, the Commission spoke in favour of basing the EU model of collective redress on

${ }^{1}$ European Parliament, Collective redress in the Member States of the European Union, 2018, p. 13-14.

${ }^{2}$ European Commission, Communication from the Commission to the European Parliament, the Council, the European Economic and Social Committee and the Committee of the Regions, 'Towards a European Horizontal Framework for Collective Redress', 11.6.2013, COM (2013).

3 European Commission in MEMO/08/741 to the Green Paper on Consumer Collective Redress - questions and answers, point nine stated '(...) US style class action is not envisaged. EU legal systems are very different from the US legal system which is the result of "toxic cocktail" - a combination of several elements (punitive damages, contingency fees, opt-out, pre-trial discovery procedures)'. 
different procedural mechanisms than the U.S. class action style, namely on representative and group actions. ${ }^{4}$

It is worth noting, however, that apart from the above mentioned major forms of collective redress in general, there are also many other procedural mechanisms at the national level, which make it possible to deliver collective redress in EU Member States. Just to mention, recently Hodges and Voet, apart from representative and group actions, identified regulatory redress, ordered or brought about by the intervention of public enforcers, civil claims piggy-backing on criminal prosecutions and consumer ombudsmen, being a specific form of alternative dispute resolution entirely separate from the courts (Hodges and Voet, 2018, p. 1-2). Although the comparative overview of existing legal tools in this field is not the subject of this paper, it needs to be underlined that collective redress mechanisms vary significantly not only worldwide, but also within EU Member States.

For the purpose of clarity of the discussion to follow, it needs to be mentioned also that there are two basic approaches, according to which affected individuals may join the group, namely systems referred to as opt-in and opt-out. In the first case, the group includes only those individuals who actively opt in to become a part of the group represented. Consequently, the judgement is binding only on those who opted in, while all the other individuals remain free to pursue their damage claims individually. By contrast, under an opt-out system the group is composed of all the individuals who belong to the specific group and claim to have been harmed by the same or similar infringement, unless they actively opt out of the group; in such a case, they are not bound by the judgement. ${ }^{5}$

Diversity of collective redress mechanisms in some Member States as regards their design, quality and operation, and lack of them in another, gave rise to different levels of consumer law enforcement in the EU. Being aware of that fact on one hand, and noting the advantages and weaknesses of collective redress on the other, the European Commission ${ }^{6}$ started to work on a framework for collective redress at the EU level.

${ }^{4}$ European Commission, Communication (2013) 'Towards a European Horizontal Framework...', op. cit.

5 The opt-in system is imposed by the legislation of most Member States, including Poland. The opt-out principle is applied by two Member States, namely the Netherlands and Portugal, while four Member States (Belgium, Bulgaria, Denmark and in competition cases also the UK) provide for a mixed system. See: European Parliament, Collective redress..., op. cit., p. 22-27.

6 To be more specific, two Directorate- General: DG SANCO and DG COMP. 


\section{Different routes to developing the legislative framework for collective consumer redress in the $\mathrm{EU}$}

The need to ensure the protection of collective consumer interests in the EU was noticed by the EU legislator in the 90s. This issue was mentioned for the first time in 1996, in the Commission's Action Plan on consumer access to justice and on the settlement of consumer disputes. ${ }^{7}$ Simultaneously, along with the performance of the action plan, the Commission drafted Directive 98/27/WE on injunctions for the protection of consumer interests, ${ }^{8}$ aimed at creating a mechanism which would make it possible to eliminate infringements of collective consumer interests. Directive 98/27/EC constituted a tool of procedural law, used in case of infringement of rights of substantive law, granted in consumer directives which were attached to the said act.

Due to the amendments introduced to Directive 98/27/EC in 2009, it was repealed by Directive 2009/22/EC on injunctions for the protection of consumer interests. ${ }^{9}$ Contrary to what is claimed by the Commission, ${ }^{10}$ the changes introduced in the new act were not significant and were more of a formal nature. To be more specific, the main and the only change introduced by Directive 2009/22/EC regards its scope and consists of updating Attachment No. 1 to the Directive, which provides the list of acts related to consumer rights. Any act which harms collective redress contrary to these provisions listed in the Attachment constitutes infringement within the meaning of Directive 2009/22/EC. Consequently, it confirmed only the status quo of the landscape of collective redress in the EU (Howells, 2017, electronic resource).

Lack of fundamental changes in the field of injunctions may be justified by the fact that the collective consumer redress model of that time introduced by Directive 298/27/EC was supposed to be complemented by another instrument, which would make it possible to claim damages for breach of competition law. In the White Paper on damages actions for breach of EC antitrust rules $(2008)^{11}$, the Commission suggested the introduction of two mechanisms of collective redress in the field of competition law, allowing consumers and

7 Communication from the Commission 'Action Plan on consumer access to justice and the settlement of consumer disputes in the internal market', 14.02.1996, COM (96)13 final.

8 Directive 98/27/EC of the European Parliament and of the Council of 19 May 1998 on injunctions for the protection of consumers' interests, OJEC, L 166/51.

${ }^{9}$ Directive 2009/22/EC of the European Parliament and of the Council of 23 April 2009 on injunctions for the protection of consumers' interests, OJEU, L 110/30.

10 According to the Commission '(...) Directive 98/27/EC [...] has been substantially amended several times', see: directive 2009/22/EC, op. cit., rec. 1.

11 European Commission, White Paper on Damages Actions for Breach of EC antitrust rules, 02.04.2008, $\operatorname{COM(2008)~} 165$ final. 
small businesses to compensate damages: representative actions brought by qualified entities such as consumer associations or state bodies and second, opt-in collective actions. As a result, in 2009 the Commission prepared the legislative Proposal for the Directive on collective actions. ${ }^{12}$ However, due to strong resistance from the business environment and heavy pressure imposed on the Commission by some Member States, the proposal was aborted (Hodges 2014, p. 72; Sorabji 2014, p. 74; Stadler 2013, p. 483). One of the arguments voiced against the proposed mechanisms was the inconsistent approach to collective redress in the field of competition and consumer law, which was caused by the fact that two Directorate General, DG COMP and DG SANCO, had different concepts as regards the future shape of the collective redress system. While the first one was in favour of the introduction of a binding mechanism in the field of compensatory redress, the second was far more vague in its suggestions in this respect. ${ }^{13}$ In order to provide coherent policy in this field, the Commissioners for competition, consumer affairs and justice were requested to work together on further developments on the collective redress system (Hodges, 2014, p. 72; Stadler, 2013, p. 483-484).

However, over the years, the proposal for the introduction of a legal instrument which enables claiming competition law damages collectively was still very controversial (Sorabji, 2014, p. 74). To this end, in order to increase the chances of its adoption, the new Proposal for a Directive on competition damages of 2013 did not mention collective actions at all. ${ }^{14}$ The political solution adopted by the Commission was to separate the proposal for collective actions in a soft law instrument. Thus, in 2013, the Commission issued its Recommendation on common principles for injunctive and compensatory collective redress mechanisms. ${ }^{15}$ The Commission indicated therein that all Member States should have collective redress mechanisms at the national level for both injunctive and compensatory relief. ${ }^{16}$ It needs to be noted, however, that the goal of this document is not to harmonise the national systems of collective redress, but to introduce non-binding, general rules which will be applicable both, in court and out-of-court proceedings (Voet, 2014, p. 97-128). Recommendation 2013/396/EU identifies specific safeguards relating to either

12 Proposal for a Directive on collective actions (2009) was withdrawn and it is not available anymore.

13 Compare: European Commission, White Paper on Damages... (2008) op. cit. and European Commission, Green Paper on Consumer Collective Redress, 27.11.2008, COM(2008) 794 final.

14 Proposal for a Directive of the European Parliament and of the Council on certain rules governing actions for damages under national law for infringements of the competition law provisions of the Member States and of the European Union, COM(2013) 404.

15 Recommendation 2013/396/EU, op. cit.

16 Ibidem, Art. 2. 
injunctive or compensatory collective redress, ${ }^{17}$ as well as common principles for both types of redress. The last category includes, among other things, the principles regarding the legal standing to bring representative actions, the admissibility of collective actions, information on collective actions, the reimbursement of legal costs of the winning party, the funding of legal actions and some general principles with regard to cross border cases. ${ }^{18}$ According to the Commission, the aim of the safeguards contained in Recommendation 2013/396/EU is to provide a barrier against abuse. ${ }^{19}$ However, at the same time, this document allows Member States for many exemptions which hampers this goal (Hodges, 2014, p. 78). Although Recommendation 2013/396/EU was supposed to do its work, latest comparative studies show that most of the Member States did not follow the principles set out by the Commission and in spite of the existing guidelines the mechanisms of collective redress are still significantly varied. ${ }^{20}$ Therefore, it may be said to justify the claim that the Recommendation itself did not contribute to establishing a common, pan-European model of collective consumer redress (Sorabji, 2014, p. 75; Hodges and Voet, 2018, p. 43).

The latest attempt to create a legislative framework for collective consumer redress was undertaken in April 2018. The European Commission issued 'A New Deal for Consumers'21, which proposed a legislative package as an answer for the new challenges of consumer policy (Jabłonowska and Namysłowska, 2018, p. 11; Kowalczyk-Zagaj, 2018, p. 120). 'A New Deal for Consumers' aims at, among other things, providing better redress opportunities for consumers, supporting effective enforcement and enhanced cooperation of public authorities in a fair and safe single market. ${ }^{22}$ In this respect, the Commission presented a Proposal for a Directive for representative actions. ${ }^{23}$ In that Proposal, the Commission wants to modernise the existing model for the protection of collective interests of consumers in the European Union, which, in principle, should improve the efficiency of collective consumer redress. The main innovation provided by the Commission is the combination of the procedure for injunctive and compensatory redress. Currently, the

17 With regard to compensatory collective redress see: Piszcz, 2017, p. 223-250.

18 Recommendation 2013/396/EU, points 4-18.

19 Ibidem, para. 10.

${ }^{20}$ European Parliament, Study on Collective redress in the Member States of the European Union, 2018.

21 Communication from the Commission to the European Parliament, the Council and the European Economic and Social Committee, 'A New Deal for Consumers', 11.04.2018, $\operatorname{COM(2018)} 183$ final, (hereinafter: 'A New Deal for Consumers').

22 'A New Deal for Consumers', op. cit., p. 4

23 Proposal for a Directive on representative actions, op. cit. 
Proposal for a Directive on representative actions is being scrutinised by the European Parliament.

The enhancement of the protection system of collective consumer interests in the European Union, as planned in 'A New Deal for Consumers', is based mainly on the legal solutions provided in the existing Directive 2009/22/EC. Therefore, for the purpose of clarity of further discussion of the new legislative framework contained in the Proposal for a Directive on representative actions, it is indispensable to present briefly some legal grounds for the functioning of the currently binding act.

\section{Model for the protection of collective consumer interests in the EU provided in Directive 2009/22/EC}

The core of the EU model for the protection of collective consumer redress is provided in Directive 2009/22/EC. The existing mechanism constitutes an instrument of procedural law, which enables consumers to enforce their rights granted in substantive law, namely in consumer directives listed in the attachment to Directive 2009/22/EC. It needs to be noted that the existing procedural measures primarily serve the purpose of eliminating the infringements and not of enabling consumers to seek compensation.

The main tool serving the purpose of exercising consumer rights granted in EU law is the action for an injunction for the protection of consumer interests. ${ }^{24}$ Directive 2009/22/EC does not regulate the type of procedure for conducting such proceedings. At the time when the Directive was introduced, Member States were entitled to decide whether the action for an injunction should be brought via judicial (civil or commercial judicial proceedings) or administrative proceedings. ${ }^{25}$ In the literature on the subject one can also find, as supported by the practice of some Member States, that the interpretation of the provisions of Directive 2009/22/EC allows national legislators to

24 Directive 2009/22/EC, op. cit., Art. 1.

25 According to European Commission '(...) two thirds of the Member States opted for a civil or commercial judicial procedure whilst only a few (Hungary, Malta, Poland and Romania, for instance) opted for mainly administrative approach. Certain Member States, even though they opted for a judicial procedure, designated administrative authorities to rule on certain infringements (Austria for television broadcasting activities and Finland for advertising for medicines for human use and for package travel, for instance).' See: Report from the Commission concerning the application of Directive 98/27/EC of the European Parliament and of the Council on injunctions for the protection of consumers' interest, 18.11.2008, $\operatorname{COM(2008)~} 756$ final, p. 4, (hereinafter: 'Report on the application of Directive 98/27/EC (2008)'). 
combine both types of proceedings in a hybrid model ${ }^{26}$ (Sieradzka 2008, LEX, Oleksiewicz 2012, LEX). Depending on the type of proceedings, the action for an injunction is brought to national courts or administrative authorities, competent in each Member State. The aim of the action is to identify and to eliminate the infringement which harms the collective interests of consumers. Therefore, the action for an injunction is said to be an instrument which belongs both to private and public law. ${ }^{27}$

Directive 2009/22/EC provides the procedural rule regulating the issue of legal standing to bring an action for an injunction. Under the Directive, it is only independent public bodies or organisations whose purpose is to protect consumer interests that are allowed to commence such proceedings (the so-called 'qualified entities', designated by the Member States) ${ }^{28}$ Such entities may a) seek an order requiring the cessation or prohibition of any infringement, ii) seek measures such as publication of the decision or iii) 'in so far as the legal system of the Member States concerned permits' - seek an order against the losing defendant to pay a fixed amount into the public purse or any beneficiary, designated in or under national legislation. ${ }^{29}$ The purpose of the action is, above all, to identify and eliminate the infringement. Measures which shall improve the enforcement of an injunction include the publication of the decision (preventive measure) and the possibility to impose a fine on the trader (repressive measure).

Directive 2009/22/EC does not specify how the individuals affected may join the group represented by the authorised entities (opt-in v. opt-out mechanisms). This is a particularly sensitive and difficult issue since it is determined by the constitutional tradition of the Member States. Within EU institutions, there is no consensus as to the choice of one principle regarding the composition of the group at the EU level. To this end, the European Commission recommends the opt-in model and justifies its standpoint, among others, by stating that it makes it possible to respect the right of a person to decide whether to participate or not and, thus, preserving the autonomy of the parties..$^{30}$ A different approach is articulated by the European Parliament which favours the opt-out or mixed system, leaving a margin of appreciation to national judges, since it is more effective and even 'more justified in

26 Such model exists, among others, in Austria and Finland.

27 On consumer redress in the field of competition law see: Sieradzka 2012.

28 Directive 2009/22/EC, op. cit., Art. 3.

29 Ibidem, Art. 2.

30 Commission Recommendation of 11 June 2013 on common principles for injunctive and compensatory redress mechanisms in the Member States concerning violation of rights granted under Union Law, 2013/396/EU, OJEU L 201/60, (hereinafter: Recommendation 2013/396/EU), para. 21-24. 
cases where exercise of "opt-in" would entail more damages, namely for the consumers, in terms of the cost of joining, and for the traders, in terms of the costs of notifying all parties involved.' 31 According to the European Parliament, the decision on the choice of the variants in question should not be left to the discretion of the Member States. ${ }^{32}$

\section{Weaknesses of the existing model}

During the period of more than 20 year, starting from the introduction of the model of the protection of collective consumer interests, the application of the legal regulation has been evaluated many times. The most valuable source of knowledge regarding the use of the action for an injunction is provided by the European Commission in the following: i) the report from the application of Directive 98/27/EC (2008), ${ }^{33}$ ii) the report from the application of Directive 2009/22/EC (2012) (34 $^{34}$ and - more recently - iii) the report on the Fitness Check (2017) ${ }^{35}$ and - finally - the report on the implementation of Recommendation 2013/396/EU on common principles for injunctive and compensatory collective redress mechanisms (2018). ${ }^{36}$ The analysis of the data provided by the Commission makes it possible to identify some key problems which concern the enforcement of consumer rights by way of the action for an injunction and the obstacles to the effectiveness of the existing mechanism.

31 European Parliament, Collective redress..., op. cit., p. 86.

32 Ibidem.

33 Report on the application of Directive 98/27/EC (2008).

34 Report from the Commission to the European Parliament and the Council concerning the application of directive 2009/22/EC of the European Parliament and of the Council on injunctions for the protection of consumers' interest, 6.11.2012, COM (2012) 635 final (hereinafter: "Report on the application of Directive 2009/22/EC (2012)').

35 European Commission, Staff Working Document: Report of the Fitness Check on consumer and marketing law directives (REFIT), 23.05.2017, SWD 2017 (208) final and SWD 2017 (209) final (hereinafter: 'Fitness Check (2017)').

36 Report from the Commission to the European Parliament, the Council and the European Economic and Social Committee on the implementation of the Commission Recommendation of 11 June 2013 on common principles for injunctive and compensatory collective redress mechanisms in the Member States concerning violation of rights granted under Union law (2013/396/EU), 25.1.2018, COM (2018) 40 final (hereinafter: 'Report on the implementation of the Commission Recommendation 2013/396/EU (2018)'). 


\section{Limited application of the cross-border actions for an injunction}

One of the most important problems of the system for the protection of collective consumer interests is the very limited application of existing tools to counter cross-border infringements. Directive 2009/22/EC, following Directive 98/27/EC, permits the qualified entities of Member State A to bring an action in Member State B if the latter, by trading with consumers in Member State A, were in breach of consumer laws. Thus, the qualified entities are vested with legal standing before foreign courts. The court in Member State B would hear and decide the case without questioning the legal standing of the qualified entity of Member State A.

However, it was demonstrated by the Commission in the reports that the proposed concept of cross-border litigation is not used in practice. By the year 2008 only one qualified entity from the UK (the Office of Fair Trading) used this mechanism in two cases, bringing an action for an injunction to the courts of Belgium and the Netherlands. ${ }^{37}$ The main reasons for the very limited use of such cross-border litigation are the costs of bringing an action, complexity and length of procedure as well as the limited scope of the injunction procedure (injunction is mandatory only with respect to the case and the parties in question and is limited in terms of the national scope). ${ }^{38}$ In spite of the fact that between the years 2008-2012 the number of cross-border cases increased (only around 70 injunctions with cross-border dimension and 5632 actions in total), most of them were not based on the concept provided in Directive 2009/22/WE. ${ }^{39}$ The traders, although established abroad, were sued in the country to which they directed their commercial activity, so in the country of origin of the consumer. The qualified entities brought actions for an injunction in their own language, own jurisdiction and in line with the applicable, national law. This allows them to avoid many practical problems, such as language barriers or difficulties of identifying and assessing the trader data abroad.

Latest data confirm that injunctions requiring the cessation or prohibition of an infringement are still not used in cross-border cases, and the qualified entities from different Member States do not cooperate enough with one another in order to exchange good practices or develop common strategies with the aim to counter widespread infringements. ${ }^{40}$

37 Report on the application of Directive 98/27/EC (2008), op. cit., p. 6.

38 Ibidem, p. 6-9.

39 Report on the application of Directive 2009/22/EC (2012), op. cit., p. 7.

40 Fitness Check (2017), op. cit., p. 102; Explanatory Memorandum of European Commission, Proposal for a directive of the European Parliament and of the Council on representative 


\section{Costs, length and complexity of the proceedings}

Directive 2009/22/EC does not regulate the issue of costs linked to the injunction proceedings and leaves it to the discretion of Member States. In order to prevent abusive litigation and frivolous claims the European Commission recommends following the principle of reimbursement of legal costs to the winning party (the so called 'loser pays principle'). ${ }^{41}$ As it is shown by the latest report, Member States largely apply this principle in their civil procedural law. ${ }^{42}$ As a result, in the light of the necessity to reimburse the costs of the opposing party, the claims are brought mostly in these cases in which the probability of winning by the qualified entity is high. What is more, in many Member States the situation of the qualified entities is difficult even if they win the case, since they may be obliged to pay costs of proceedings anyway if the losing defendant is unable to pay the costs. ${ }^{43}$

Latest data show that the financial risk linked to the proceedings for an injunction is the most crucial obstacle which limits the number of actions for an injunction brought by qualified entities, and therefore it considerably impairs the effectiveness of the collective redress mechanism in the whole EU. ${ }^{44}$

Another obstacle to the effectiveness of actions for an injunction is the length and complexity of the procedure. ${ }^{45}$ The glaring example of the lengthiness of the proceedings can be demonstrated by one of the biggest group proceedings in Poland. In this case, the municipal consumer ombudsman (Pol. miejski rzecznik konsumentów) brought a claim against BRE Bank S.A. (currently mBank S.A.) on behalf of 1247 clients of the bank. The case concerned consumers who concluded mortgage loan agreements according to which the rate of the loan was subject to indexation in Swiss francs. The agreements contained a condition which allowed the bank to change the interest rate at its own discretion. In simple terms, the bank increased the interest rate due to economic changes, which was unfavourable to consumers and did not decrease the interest rates when the market situation changed to the benefit of consumers (Niedużak and Szwast, 2014, p. 9-11). The case was adjudicated

actions for the protection of the collective interests of consumers, and repealing Directive 2009/22/EC, 11.4.2018, COM(2018), 184 final, p. 8.

41 Recommendation 2013/396/EU, op. cit., para. 13.

42 All Member States that have collective redress mechanisms, with the exception of Luxembourg, follow the 'loser pays' principle in their civil procedural laws. See: European Commission, Report on the implementation of the Commission Recommendation 2013/396/EU (2018), op. cit., p. 8 .

43 Report on the application of Directive 2009/22/EC (2012) p. 11.

44 Fitness Check (2017), op. cit., p. 103.

45 Ibidem, p. 104. 
at the courts of all instances. ${ }^{46}$ However, the bank successfully appealed to the Supreme Court of Poland ${ }^{47}$ and consequently the case must be adjudicated again by the court of second instance in Łódź. The case is still pending. It has been ongoing for over 8 years. ${ }^{48}$ The course of the proceedings and in particular - the controversial judgment of the Supreme Court have been widely discussed and criticised in the doctrine (Czabański, 2016, p. 182-188, Czech, 2016, p. 56-65).

\section{Limited effect of the ruling with respect of the case and the parties involved}

Another significant problem related to the use of actions for an injunction is the limited effect of the ruling. ${ }^{49}$ Studies conducted by the European Commission confirmed that in most of the Member States an injunction order is issued with respect of the case and the parties involved. This means that it binds only the qualified entity which brought an action for an injunction and the defendant trader (inter partes effect).$^{50}$ In practice, if one trader will infringe the rights of consumers and the infringement is identical to the infringement committed by another trader, confirmed by an earlier the judgment, the consumer cannot rely on the previous injunction order but must prove the infringement anew. This poses problems for the effectiveness of an injunction order and therefore, obviously, it increases the litigation risk and causes costs to the justice system. ${ }^{51}$

Only some of the Member States in their legal orders extend the effects of the decisions issued as a result of an action for an injunction to other parties (erga omnes effect), in particular with regard to the nullity of unfair contract terms. ${ }^{52}$ Extending the effects of injunctions beyond the individual case has the advantage that it prevents the repeated use of that term. ${ }^{53}$ However, some

46 Judgement of the court of the first instance in Łódź dated 03.07.2013, case no. II C 1693/10; judgment of the court of the second instance in Łódź, dated 30.04.2014, case no. I ACa 1209/13 (in favour of consumers).

47 Judgment of 14.05.2015, case no. II CSK 768/14.

48 Currently the proceeding takes place before the Court of Appeal in Łódź (Sąd Apelacyjny w Łodzi), under sign. I ACa 1058/15.

49 Report on the application of Directive 2009/22/EC (2012), op. cit., p. 13-16.

50 Report on the application of Directive 98/27/EC (2008), op. cit., p. 9; Report on the application of Directive 2009/22/EC (2012), op. cit., p. 14.

51 Fitness Check (2017), op. cit., p. 104.

52 Report on the application of Directive 98/27/EC (2008), op. cit., p. 9; Report on the application of Directive 2009/22/EC (2012), op. cit., p. 14.

53 Opinion of Advocate General delivered on 06.12.2011 in case C-427/10 Invitel, ECLI:EU:C:2011:806, para 69. 
national courts had doubts as regards the compliance of such regulation of national law with EU law, especially with regard to Directive 93/13/EEC on unfair terms in consumer contracts. ${ }^{54}$ Therefore, this issue was analysed by the Court of Justice of the European Union (hereinafter: the Court).

For the very first time this question was analysed by the Court in the case C-472/10 Invitel, ${ }^{55}$ where the proceedings before the Court were commenced as a consequence of a reference for a preliminary ruling lodged by a Hungarian court. The reference has been made in the context of public interest proceedings brought by the Hungarian national consumer protection authority (hereinafter: NFH) against the company Invitel - a telephone network operator. NFH alleged that Invitel used unfair terms in contracts concluded with consumers, which made consumers pay fees that had not initially been agreed upon between the parties. The Hungarian national consumer protection authority declared the contested term to be null and void on the grounds of being unfair and automatic and imposed a retroactive reimbursement to the subscribers of the amounts wrongly invoiced. The national court was not sure whether it can declare the invalidity of an unfair term with regard to all the consumers who have concluded a contract with unfair contract terms or only with regard to those consumers who are a party to the proceedings.

When answering this prejudicial question, the Court recalled the idea that the consumer is in a weak position towards the trader as regards both his bargaining power and his level of knowledge. ${ }^{56}$ As a consequence, consumers agree to the terms drawn up in advance by the trader without being able to influence the content of those terms. The Court referred to Article 6 of Directive 93/13/EEC, which provides that unfair terms shall, as provided for under the national law, not be binding for the consumer and stated that the aim of this provision is to replace the formal balance of the contracting parties and to re-establish equality between them. ${ }^{57}$ At the same time, the Court said that the extension of the effects of an injunction to all consumers is justified due to the deterrent nature and dissuasive purpose of the action for an injunction. ${ }^{58}$ Therefore, the Court adjudicated that the declaration of invalidity of an unfair contract term effects with regard to all consumers who concluded with the seller or supplier concerned a contract to which the same

${ }^{54}$ Council Directive 93/13/EEC of 5 April 1993 on unfair terms in consumer contracts, OJEC no. L95/29.

55 Judgement of the Court of Justice of the European Union dated 26 April 2012, C-472/10 Nemzeti Fogyasztóvédelmi Hatóság v. Invitel Távközlési Zrt, ECLI:EU:C:2012:242.

56 Ibidem, para. 33

57 Ibidem, para. 34

58 Ibidem, para. 37. 
terms apply, including those consumers who were not party to the injunction proceedings. ${ }^{59}$

Moreover, Court stated that Directive 93/13/EEC does not preclude ' $(. .$. where the unfair nature of a term in the general business conditions has been acknowledged in such proceedings, national courts are required, of their own motion, and also with regard to the future, to take such action thereon as is provided for by national law in order to ensure that the consumers who have concluded a contract (...) will not be bound by that term. ${ }^{60}$ By virtue of the above, the Court approved of the extension of res judicata of the decision on the declaration of unfairness of a contract term to consumers who are not party to the proceedings. However, it is pointed out in literature on the subject that the Court imposed the obligation on national courts to recognise pro futuro the effect of the declaration of unfairness only to those Member States that recognise the erga omnes effect of an injunction (Keirsblick, 2013, p. 1473).

The question of the extension of the legal effects of an injunction order as regards other parties was also discussed by the Court in the case C-119/15 Partner. ${ }^{61}$ The judgement was issued as a consequence of a reference for a preliminary ruling requested by a Polish court. The referring court asked whether a judicial decision, having the force of law, which declared the contract terms unlawful and, as a result, had them entered into the register of unlawful standard contract terms, can have the effect not only on the trader being a party to the proceedings, but also in relation to other traders who use identical unlawful standard contract terms. In the case in question, the Polish court adjudicated on the appeal of Biuro Partner against the decision of the President of the Office of Competition and Consumer Protection (hereinafter: UOKiK) issued in an administrative procedure (the original UOKiK decision was upheld by the court of first instance). In the administrative decision the President of UOKiK found that Biuro Partner in its standard conditions of business used terms which were considered equivalent to terms previously declared unlawful, and consequently entered into the public register of unfair terms. The President of UOKiK stated that those terms harmed collective interests of consumers and imposed a fine on the company. The Polish court had doubts as to such decision since Biuro Partner did not participate in the proceedings in which the standard terms were declared unlawful and consequently entered into the public register.

The Court, however, stated that the extended effect of the entry into the public register of unfair terms does not contradict EU law on the condition

\footnotetext{
59 Ibidem, para. 44.

60 Ibidem.

61 Judgement of the Court of Justice of the European Union dated 21 December 2016, C-119/15 Biuro podróży 'Partner' sp. z o.o. sp. k. v., Prezes UOKiK, ECLI:EU:C:2016:987.
} 
that the trader is vested with the relevant procedural guarantees. ${ }^{62}$ The main requirement here is to ensure that the trader has an effective judicial remedy both against the decision declaring that the terms are equivalent to the terms entered into the said register (in terms of the question whether those terms are substantively identical and having regard in particular to their harmful effects for consumers) and against the decision stating the amount of the fine imposed. ${ }^{63}$

Applying the reasoning presented by the Court in the cases Invitel and Partner, it may be argued that the extension of the effects of an injunction order both on all consumers affected by the unfair contract terms and on the traders who use such terms in consumer contracts is welcome at the EU level. However, it should be noted that the decision regarding legal effects of the injunction is left at the discretion of Members States. In both cases, the Court does not impose the obligation on the Member States to recognise the erga omnes effect of an injunction order, but it states that such wording of the national law does not contradict EU law (Wyżykowski, 2018, p. 114-115).

\section{Limited spectrum of legal remedies}

The only legal consequence of the injunction procedure available under Directive 2009/22/EC is the prohibition to continue the infringement by the trader. The Directive does not provide any further remedies which would remove the consequences of the infringement of consumer rights. The European Commission emphasises that ' $(. .$.$) as a general rule, the injunction$ procedure introduced by the Directive does not enable consumers who have suffered harm because of an illicit practice to obtain compensation. ${ }^{64}$

In my view, this limited effect of the injunction procedure designed by Directive 2009/22/EC on consumer redress possibilities constitutes the main problem which hampers the effectiveness of the mechanism in question. The fact that consumers cannot seek compensation together with seeking an injunction and, therefore, are forced to commence separate proceedings poses unnecessary litigation risks and increases costs not only for consumers but also for the whole justice system. It also discourages consumers from pursuing their claims collectively since even a successful action for an injunction may not result in positive financial implications.

It is reported that in most Member States consumers cannot rely on injunction orders and in order to claim compensation they have to bring

\footnotetext{
62 Ibidem, para. 47

63 Ibidem, para.

64 Report on the application of Directive 2009/22/EC (2012), p. 9.
} 
a separate claim for damages (either individually or collectively). ${ }^{65}$ In many Member States, the courts which adjudicate compensation claims are not bound by a previous injunction order. ${ }^{66}$ Consumers have to prove the infringement (anew), to prove the damage and - finally - the link between the infringement and the damage. Only in some Member States, consumers are able to rely on injunction orders in their follow-on action for compensation where they then have to prove only the amount of the damage suffered. ${ }^{67}$

\section{Change for the better? Proposal for a Directive on representative actions}

Outcomes revealed in the report on the implementation of the Commission Recommendation 2013/396/EU published in 2018 confirmed the concerns articulated by some scholars as regards abidance of the safeguards provided in Recommendation 2013/396/EU (Stadler, 2013, p. 488; Sorabji, 2014, p. 75; Hodges, 2014, p. 78; Howells, 2017; electronic resource, Money-Kyrle, 2016, p. 251). It leaves no doubt that the non-binding instrument is not a sufficient tool to provide procedural coherence and therefore to ensure a homogenous landscape of collective redress in the EU. Although the Commission recommended for all Member States to have collective redress mechanisms at the national level, for both injunctive and compensatory relief, nine Member States did not introduce mechanisms for compensatory collective claims. ${ }^{68} \mathrm{On}$ the other hand, it was also clear that the procedural mechanism provided in Directive 2009/22/EC - action for an injunction - is not by itself a sufficient instrument to enforce consumer rights. Keeping in mind the above mentioned lack of legislation in this field at the national level on the one hand, and being aware of the problems hampering the effectiveness of the injunction procedure as designed by Directive 2009/22/EC on the other, the European Commission commenced works on new legislation which allows to modernise and complement the existing system of the protection of collective interests of consumers in the EU.

65 Report on the implementation of the Commission Recommendation 2013/396/EU (2018), p. 18.

66 Ibidem.

67 The Commission Report (2018) revealed that 'In Denmark, Belgium and Italy it is possible to rely on an injunctions decision in a follow-on collective action in consumer law cases (...) In Netherlands follow-on actions are possible not as a matter of law but rather of practice.'

68 Report on the implementation of the Commission Recommendation 2013/396/EU (2018), p. 3. 
As a result, in the Proposal for a Directive on representative actions, the Commission tries to combine the procedural mechanisms existing in Directive 2009/22/EC (that is, the action for an injunction) and mechanisms which, due to a political consensus, were finally included in Recommendation 2013/396/EU, namely the action for compensation. In this sense, one may say that the Proposal for a Directive on representative actions constitutes a continuum of the concept which due to political resistance has so far never been included in a binding act.

As far as the form of collective redress is concerned, the works resulted in the Commission proposing an act which follows the same patterns as Directive 2009/22/EC. The proposed Directive on representative actions is based upon the old structure, namely the principle according to which Member States designate their qualified entities to represent the collective interests of consumers. Such procedural mechanism, which under Directive 2009/22/EC exists in relation to injunctions, was proposed by the Commission already in 2008 in relation to compensatory collective claims in the field of antitrust law, ${ }^{69}$ unfortunately without success. Similarly, as it is regulated in existing legislation, in the proposed act representative entities may bring representative actions in the case of a violation of rights granted in EU consumer law, listed in the Attachment to the Proposal. It also keeps the freedom of choice given to Member States with regard to the decision on the procedure of bringing representative actions. Legal remedies can be claimed within judicial or administrative proceedings or both, depending on the field of law or business sector.

The main difference between both acts consists of the extension of the redress measures which may be claimed by the qualified entities on behalf of consumers. According to the Proposal, different remedies can be sought within one representative action, or many different actions. In addition to the existing possibility to seek an injunction order (but in the extended scope, also as an interim measure), the Proposal provides for the possibility to seek compensatory redress also. This is why the Proposal shall be also examined as a continuum of the provisions set forth in the non-binding Recommendation 2013/396/EU. Due to the extension of the scope of the proposed act - I believe - the terminology has been changed in the Proposal: the existing term 'action for an injunction for the protection of consumers' collective interests' designed by the directive 2009/22/EC is going to be replaced by the term 'representative action', which according to the definition of collective redress used in Recommendation 2013/396/EU refers to both injunctive and collective redress. ${ }^{70} \mathrm{It}$ is worth considering, whether the proposed act does answer the

${ }^{69}$ European Commission, White paper (2008), op. cit., p. 4.

70 Recommendation 2013/396/EU point II 3 a. 
problems which have hindered the effectiveness of Directive 2009/22/EC, as discussed above.

\section{Cross-border representative actions}

The proposed Directive for representative actions keeps the model of cross-border representative actions, which permits qualified entities from Member State A to apply to the courts or administrative authorities in Member State B if the traders from B are in breach of consumer law while trading with consumers from Member State A. ${ }^{71}$ Exactly the same way as it is under Directive 2009/22/EC, Member States would have to present to the Commission a list of qualified entities, designated in advance.

Notably, no specific procedure for cross-border representative actions has been proposed. Lack of regulation in this respect implies for the qualified entities the necessity to get acquainted with the relevant legal regulations of another Member State (judicial or administrative, depending on the legal order of the Member States). Exactly the same way as it is practised under the current law, it will entail some financial consequences, namely the qualified entity must bear the costs of the preparation of the claim, court fees, remuneration of the lawyers from different jurisdictions, or costs of translation. Additionally, one may expect that bringing cross-border claims will be hindered by uncertainty as for the choice of applicable law governing the dispute in point. The Proposal of the Directive for representative actions does not provide or refer to any private international law rules regarding the competent courts, the recognition and enforcement of the judgements or choice of applicable law and it does not refer to any other act of EU law (Biard, 2018, p. 201). Leaving this area unregulated, the Proposal follows the old pattern set in Recommendation 2013/396/EU (Stadler, 2013, p. 484).

The legal situation of consumers can be even more complex in case of representative actions brought by the same qualified entity for the protection of collective interests of consumers from different Member States. The Proposal provides for the possibility to bring an action by a single qualified entity on behalf of the consumers from different Member States affected (or likely to be affected) by the same infringement, committed by a trader. Such cross-border action may also be brought to the competent court or administrative authority by several representative authorities acting jointly. Although the idea of the introduction of the possibility to commence such proceedings is - indeed justified by the need of ensuring the effectiveness of the procedure, the lack

71 Proposal for a Directive on representative actions, op. cit., Art. 16. 
of any guidance as to the course of such cross-border proceedings is very surprising, since it will certainly pose many legal difficulties.

\section{Legal costs and financing the qualified entities}

Another obstacle hampering the effectiveness of the injunction procedure in its current shape is caused by high costs of proceedings commenced by the action for an injunction. Under the current Proposal, this problem seems to be unsolved. On the one hand, the Proposal states that Member States shall ensure that that procedural costs related to representative actions shall not constitute financial obstacles to the qualified entities, and this shall be achieved by limiting the costs of judicial and administrative proceedings, granting access to legal aid and providing the entities with public funding. ${ }^{72}$ On the other hand, however, the proposed Directive left it to the discretion of Member States to regulate the amount of costs of the injunction proceedings. According to the Proposal, this act should not affect the national rules concerning the allocation of procedural costs. ${ }^{73}$

It's worth noting that the legal framework proposed still applies the principle according to which the costs of the injunction procedure are to be borne by the qualified entity bringing representative action. At the same time, the Proposal states that the procedural costs of the proceedings shall not prevent the qualified entities from effectively exercising the right to seek redress. Although the Proposal does not regulate this question directly, it gives some guidance as regards the possibility of funding of the qualified entities.

An interesting innovation introduced in the Proposal for a Directive on representative actions is the possibility to finance the activity of the qualified entities from the private sector, among other things, from the business environment. Member States may decide whether the qualified entities financed by third parties will be allowed to seek all the redress measures available (including compensatory collective redress) or only some of them. As regards the entities seeking compensatory collective redress, the EU legislator provides for an additional obligation to declare the source of the funds used for its activity in general and the funds that it uses to support the action. ${ }^{74}$ Additionally, the qualified entities have to demonstrate that they have sufficient financial resources to meet any adverse costs should the action fail. At the same time, the Proposal prohibits third party funding in case of

\footnotetext{
72 Ibidem, Art. 15.

73 Ibidem, rec. 4.

74 Ibidem, Art. 7.
} 
actions brought against a defendant who is a competitor of the fund provider or against a defendant on whom the fund provider is dependent.

\section{Duration of the proceedings}

Following the need to ensure effectiveness of the proceedings, the EU legislator provides that representative actions shall be treated with due expediency. ${ }^{75}$ By way of exception, a representative action for an injunction order in the form of interim measure shall be treated according to an accelerated procedure. The purpose of this procedure is to ensure that any further harm that may be caused by a trader's practice subject to representative action may be prevented as quickly as possible. ${ }^{76}$ However, the legislator does not provide for any guidance as to the course of those proceedings and it does not provide any difference between both types. There being no precise regulations in this respect, it is doubtful whether it will constitute a turning point making it possible to shorten the time of the proceedings.

\section{Extended scope of application}

The proposed Directive extends the scope of the application of representative actions on two fields. Firstly, the projected mechanism shall cover a variety of areas, such as data protection, financial services, travel and tourism, energy, telecommunication and environment. ${ }^{77}$ The ratio legis for such solution is to cover the infringements of EU law protecting the interests of consumers, regardless of whether they are referred to as travellers, users, customers, retail investors, retail clients or another in the relevant EU law. ${ }^{78}$ Therefore, Attachment No. 1 to the Proposal of a Directive, listing EU legal acts relevant for the protection of collective interests of consumers, was updated and extended, compared to the one, attached to Directive 2009/22/EC.

Secondly, the Proposal extends the redress measures which may be sought by the qualified entities within one or many proceedings. Following the pattern of Directive 2009/22/EC, the Proposal provides that the qualified entities may seek an injunction order (interim or definite measure) in order to stop or

75 Ibidem, Art. 12.

76 Explanatory Memorandum to the Proposal for a directive on representative actions, op. cit., point. 5.

77 Proposal for a directive on representative actions, op. cit., rec. 6.

78 Ibidem. 
prohibit the trader's practice. ${ }^{79}$ The significant change, however, is caused by introducing a different measure, aiming at the elimination of the continuing effect of infringement. In this respect the Proposal provides for the possibility to seek compensatory redress, or - in line with the terminology used in the Proposal - representative actions for compensation. In the redress order, a trader may be obliged to provide for, among other things, compensation, repair, replacement, price reduction, contract termination or reimbursement of the price paid (compensatory redress mechanisms). ${ }^{80}$ It goes without saying that the introduction of the possibility to seek compensation constitutes the most important legislative change which shall result in an increase of the number of actions brought on behalf of consumers.

The proposed act introduced the principle according to which proceedings initiated by collective actions for compensation, which were adjudicated in favour of consumers, shall be finalised with a redress order. Only under special circumstances - instead of a redress order - the court or administrative body may issue a declaratory decision regarding the liability of the trader towards the consumers harmed by an infringement of EU law. This discretion is granted only in duly justified cases where, due to the characteristics of the individual harm to consumers concerned, the quantification of individual redress is complex and thus ineffective to be quantized within representative action. ${ }^{81}$ Such declaratory decision may be directly relied upon in subsequent redress actions (both in individual and collective actions)..$^{82}$

The possibility to issue a declaratory decision is strictly excluded in two cases which regard mass harm situations. ${ }^{83}$ The first relates to cases where the consumers concerned by the infringement are identifiable and they suffered harm which is comparable to the one caused by the same practice with regard to the period of time or a purchase. ${ }^{84}$ The second one concerns cases where consumers suffered an insignificant loss and it would be disproportionate to distribute the redress to them. ${ }^{85}$ In such cases, the redress shall be diverted to public purposes serving the collective interests of consumers, such as awareness campaigns, consumer legal aid funds or consumer movements. ${ }^{86}$

\footnotetext{
79 Proposal for a directive on representative actions, op. cit., Art. 5.

80 Proposal for a directive on representative actions, op. cit., Art. 6.

81 Proposal for a directive on representative actions, op. cit., Art. 5.

82 Explanatory Memorandum to the Proposal for a directive on representative actions, op. cit., point 1 .

83 Ibidem.

${ }^{84}$ Proposal for a directive on representative actions, op. cit., Art. 5.

85 Ibidem.

86 Proposal for a directive on representative actions, op. cit., rec. 21.
} 


\section{Evaluation of the changes proposed}

It seems to be indisputable that a modification of the existing system of collective redress for consumers is to be welcomed. It remains doubtful, however, whether the changes proposed by the Commission will really contribute to the modernisation of this system. The idea of including compensatory collective redress in the EU system is definitely one of the most vital and positive amendments proposed by the Commission. One may expect that the possibility to seek compensation collectively will motivate consumers to enforce their rights towards traders. However, as it is demonstrated in the paper, the idea to include compensatory collective redress in the binding legal instrument is not entirely new and over the years was highly controversial, mainly due to the strong resistance from the business sector and some Member States. Thus, reaching a consensus as regard the European framework for collective redress in the shape as proposed by the Commission seems to remain questionable.

It shall be also noted that bearing in mind that consumers are not willing to bear the costs of the proceedings, the qualified entities must be equipped with appropriate funds used for their activity. To this end, the possibility of third-party funding seems to be promising. One may say that, contrary to the Commission's claims, inflow of third-party capital will bring 'representative actions, European way' ${ }^{87}$ somehow closer to the U.S. class action style in that sense that the proceedings might be financed by the business sector. Therefore, the question of the control of the source of the funds must be regulated in more detail in order to prevent third party traders from providing financing for collective actions against their competitors or dependant entities. Otherwise, third party funding can result in abusive or frivolous litigation, feared by the Commission.

Moreover, it is surprising that while being aware of many problems arising out of the application of Directive 2009/22/EC, and caused by its vagueness, these issues were not addressed by the Commission in the proposed legislation. Under the Proposal, the question of the length and costs of injunction proceedings seems to be unregulated. Similarly, the difficulties relating to cross-border proceedings remain unsolved.

Quite in the same spirit, it shall be criticised that the margin of appreciation left to Member States is so wide. This issue is not new and has been raised already in relation to the safeguards contained in Recommendation 2013/396/EU, which allows Member States for many exemptions (Hodges, 2014, p. 78). Perhaps the most vivid example here is leaving the choice to the

${ }^{87}$ European Commission, press release: http://europa.eu/rapid/press-release_IP-18-3041_ en.htm, accessed: 08.06.2019. 
Member States as regards the system of joining the group. The Proposal for a Directive on representative actions does not specify whether it should be the opt-in, opt-out or a mixed system. In my view, leaving this crucial point to the discretion of Member States excludes the possibility of the creation of a coherent system of collective redress at the EU level. This - in turn - may bring some doubts with regard to the enforcement of injunctive orders issued in the course of injunction proceedings at the EU level. It is a commonly known fact that better coherence implies better enforcement of the law. However, it may be argued that instead of specific solutions in this respect, the Commission should go further than issuing vague declarations.

Keeping in mind all of the above mentioned, it seems to be doubtful whether the current Proposal for a Directive on representative action will significantly improve the European landscape of collective redress and strengthen the mechanism for the protection of collective consumer interests.

\section{Literature}

Biard, A. (2018). Collective redress in the EU: a rainbow behind the clouds, ERA Forum, 19, 189-204.

Cafaggi, F. and Micklitz, H. (2008). Collective enforcement of consumer law: a framework for comparative assessment, European Review of Private Law, 3, 391-425.

Czabański, J. (2016). O klauzulach abuzywnych w tzw. kredytach walutowych. Glosa do wyroku SN z dnia 14 maja 2015 r., II CSK 768/14, Palestra, 1-2, 182-188.

Czech, T. (2016). Odpowiedzialność banku za stosowanie abuzywnej klauzuli zmiennego oprocentowania. Glosa do wyroku SN z dnia 14 maja 2015 r., II CSK 768/14, Monitor Prawa Bankowego, 6, 56-65.

Durovic, M. and Micklitz, H. (2017). Internationalization of consumer law: a game changer, Springer.

Hodges, C. (2014). Collective redress: A Breakthrough or a Damp Sqibb?, Journal of Consumer Policy, 37, 67-89.

Hodges, C, and Voet, S. (2018). Delivering collective redress. New technologies, Hart.

Howells, G. (2017). EU consumer access to justice and enforcement. In Howells G., Twigg-Flesner C., Wilhelmsson T. (eds). Rethinking EU consumer law, Routledge, (electronic resource).

Ioannidou, M. (2011). Enhancing the consumer's role in EU private competition law enforcement: a normative and practical approach, The Competition Law Review, 8(1), $59-85$.

Jabłonowska, A. and Namysłowska, M. (2018). Nowy ład konsumentów? O planowanych zmianach prawa konsumenckiego w Unii Europejskiej, Europejski Przeglad Sądowy, 10, 11-17.

Keirsblick, B. (2013). The erga omnes effect of the finding of an unfair contract term: Nemezi, Common Market Law Review, 50(5), 1467-1478. 
Kowalczyk-Zagaj, A. (2018). Przegląd najważniejszych propozycji legislacyjnych Komisji Europejskiej w „Nowym ładzie dla konsumentów”, internatowy Kwartalnik Antymonopolowy i Regulacyjny, 6(7), 119-131.

Money-Kyrle, R. (2016). Legal Standing in collective redress actions for breach of EU rights: facilitating or frustrating common standards and access to justice? In Hess B., Bergstrom M., Storskrubb E. (eds), EU Civil Justice: Current Issues and Future Outlook, Hart, 223-256.

Niedużak, M. and Szwast, M. (2014). Pozwy grupowe- doświadczenia po czterech latach, Helsinska Fundacja Praw Człowieka.

Oleksiewicz, I. (2012). Dyrektywa Parlamentu Europejskiego i Rady 2009/22/WE z dnia 23 kwietnia $2009 r$. $w$ sprawie nakazów zaprzestania szkodliwych praktyk $w$ celu ochrony interesów konsumentów. Komentarz, Lexis Nexis.

Piszcz, A. (2017). Compensatory collective redress: will it be part of private enforcement of competition law in CEE countries?, Yearbook of Antitrust and Regulatory Studies, 10(15), 223-250.

Sieradzka, M. (2012). Pozew grupowy jako instrument prywatnoprawnej ochrony interesów konsumentów z tytułu naruszenia regut praw konkurencji, Wolters Kluwer.

Sieradzka, M. (2008). Komentarz do dyrektywy 98/27/WE w sprawie nakazów zaprzestania szkodliwych praktyk w celu ochrony interesów konsumentów. In Sieradzka M. (ed.), Ustawa o ochronie konkurencji i konsumentów. Komentarz, LEX.

Sorabji, J. (2014). Reflections on the Commission Communication on Collective redress, Irish Journal of European Law, 17(1), 62-76.

Stadler, A. (2013). The Commission's Recommendation on common principles of collective redress and private international law issues, Nederlands International Privatrecht, 4, 483-488.

Wyżykowski, B. (2018). Skuteczna ochrona konsumentów a gwarancje procesowe przedsiębiorców. Glosa do wyroku TS z 21 grudnia 2016 r. w sprawie C-119/15 Biuro podróży Partner sp. z o.o. sp. k przeciwko w Dąbrowie Górniczej przeciwko Prezesowi Urzędu Ochrony Konkurencji i Konsumentów, internetowy Kwartalnik Antymonopolowy i Regulacyjny, 4(7), 107-122.

Wyżykowski, B. (2017). Skutki uznania abuzywności postanowienia umowy w kontroli incydentalnej, internetowy Kwartalnik Antymonopolowy i Regulacyjny, 8(6), 76-98.

Voet, S. (2014). European collective redress: a status quaestionis, International Journal of Procedural Law, (4)1, 79-128. 